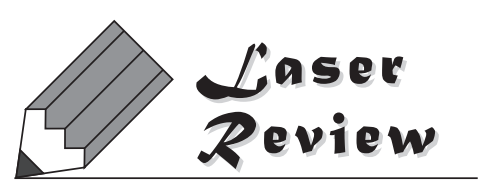

\title{
高出力量子カスケードレーザーの現状と将来展望
}

\author{
枝村忠孝 ${ }^{1}$, 秋草 直大 ${ }^{1}$, 山西 正道 ${ }^{1}$, 石井 克典 ${ }^{2}$, 粟津 邦男 ${ }^{2}$ \\ 1浜松ホトニクス(株)（广434-8601 静岡県浜松市浜北区平口5000） \\ ${ }^{2}$ 大阪大学大学院 工学研究科 ( $5565-0871$ 大阪府吹田市山田丘2-1)
}

\section{Recent Progress on High-Power Quantum Cascade Lasers and Future Prospects}

\author{
Tadataka EDAMURA, ${ }^{1}$ Naota AKIKUSA, ${ }^{1}$ Masamichi YAMANISHI, ${ }^{1}$ Katsunori ISHII, ${ }^{2}$ and Kunio AWAZU ${ }^{2}$ \\ ${ }^{1}$ HAMAMATSU PHOTONICS K.K., 5000 Hirakuchi, Hamakita-ku, Hamamatsu, Shizuoka 434-8601 \\ ${ }^{2}$ Graduate School of Engineering, Osaka University, 2-1 Yamadaoka, Suita, Osaka 565-0871
}

(Received November 27, 2012)

\begin{abstract}
During the last decade, the development of Mid-IR $(4 \sim 11 \mu \mathrm{m})$ Quantum Cascade Lasers (QCLs) has shown substantial progress toward to the commercial availability of such devices. In developing newly high performance QCLs, we focused on high-power QCLs for bio-medical applications, and developed a Fabry-Perot (FP-) type QCL emitting at the 6- $\mu \mathrm{m}\left(\sim 1700-\mathrm{cm}^{-1}\right)$ wavelength range. This wavelength range is expected to be absorbed by organic matter. The active region structure of QCL is based on InGaAs/InAlAs super lattice grown by MOCVD. High reflection coated FP-QCL chip is mounted episide down on the $\mathrm{Cu}$ heat-sink. The average output power exceeds $1.1-\mathrm{W}$ in pulsed operation (dutycycle $50 \%$ ) at $20^{\circ} \mathrm{C}$. High-power QCLs show good potential for less-invasive and selective laser surgery.
\end{abstract}

Key Words: Mid-IR, High-power, Quantum Cascade Laser, Laser Surgery

1.はじめに

量子カスケードレーザー(Quantum Cascade Laser: QCL) は半導体量子井戸中に形成されるサブバンド間の 電子遷移を利用した半導体レーザーである。サブバンド 間で光増幅が可能であることは1971年, Kazarinovと Surisによって議論 11 されたが, サブバンド間では超高速 で起こる非発光緩和過程との競合が不可避であり, レー ザー発振に必要な反転分布を形成することが極めて困難 であることから，実現は不可能と考えられていた．とこ ろが1994年, FaistとCapassoらはInGaAs/InAlAs超格子構 造を用いて, 波長4.2 $\mu \mathrm{m} て ゙$ 初めてレーザー発振に成功 ${ }^{2)}$ した。彼らは共鳴トンネル効果を用いて効率的に発光上 位準位に電子を注入し, 且つ極性縦光学フォノン (LOphonon)散乱を利用して超高速に発光下位準位から電子 を引き抜くことにより実効的な反転分布を実現した．当 初は極低温動作に限られていたが，2002年に室温連続発 振が達成 ${ }^{3)}$ された。既に，波長 $4 \sim 11 \mu \mathrm{m}$ の中赤外領域で は研究開発レベルを脱し, 実用的汎用半導体レーザーと して市販されており，各種分析装置への実装も行なわれ ている，これまでのところ最も成功している応用例は吸 収分光法に基づく環境ガス計測であり，光源に要求され る出力レベルは数十 $\mathrm{mW}$ から $100 \mathrm{~mW}$ 程度である。これ
に対してレーザー加工や生体分野ではワットクラスの高 出力化が要求されている. 現在, 我々は医療応用を目指 して波長6 $\mu \mathrm{m}$ 帯で高出力化の研究開発を進めており, 本稿では単素子でワットクラスの出力が可能な高出力 QCLの現状および今後の展望について概観する。また, 応用の一例として我々が取り組む, 高出力QCLを用いた レーザー医療についても紹介する.

\section{2. 量子カスケードレーザーの特徴}

Fig. 1に模式的に表した典型的な3つのサブバンドから なるQCLの活性領域の伝導帯におけるバンド図を示す. 発振波長はE3-E2で決定され，E2-E1は電子を高速緩 和させるためにLOフォノンのエネルギーに共鳴する(30 〜 40 meV) ように設計されている.このような構造が多 段に直列に結合 (カスケード結合)して活性領域が構成さ れている。電子注入層は量子井戸の幅が徐々に狭くなっ ていくチャープ超格子構造となっており, 動作状態では 素子にかかる電圧によって実効的なバンドが平坦とな り, 電子注入層から共鳴トンネル効果によって発光層に 形成されたE3へ電子の注入が行われる，QCLはサブバ ンド間の電子遷移を利用することで次に示すような利点 を有する。 


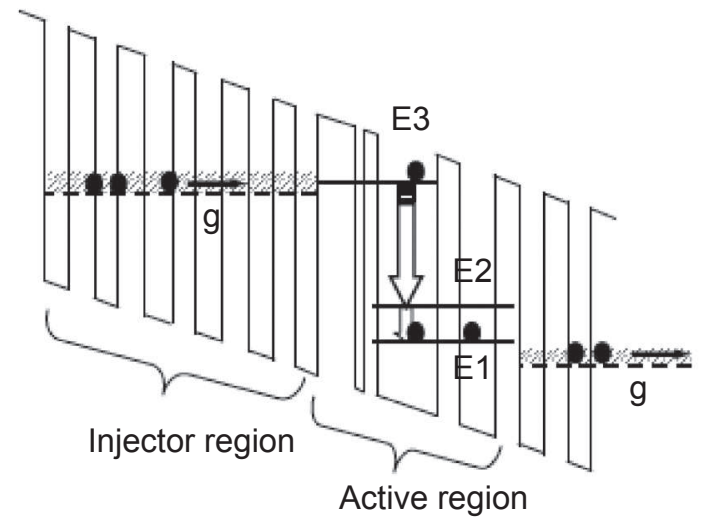

Fig. 1 Schematic conduction band diagram of one period of the laser structure under an applied voltage.

（1）発振波長は材料のバンドギャップに制限されず同一 材料で中赤外から THz帯まで設計可能.

（2）GaAsやInGaAsといったこれまで実績のある材料で 実現でき，既存の結晶成長技術およびプロセス，組 立技術をそのまま利用できる。

（3）カスケード結合を利用することで注入電子1個当り 複数の光子を放出することが可能であり, 高出力動 作が期待できる。

（4）非常に高速な非発光緩和過程に起因して本質的にス ペクトル線幅が狭い ${ }^{4,5)}$.

Fig. 1に示すような3準位系のモデルにおいてE3とE2の 電子数および光子数に対するレート方程式を解いてしき い值電流 $I_{\mathrm{th}}$ を求めると次式のようになる.

$$
I_{\mathrm{th}}=e P_{\mathrm{th}}=e\left(n_{\mathrm{sp}} / \eta\right)\left[\frac{\gamma}{M \beta_{\text {eff }}}+\frac{N_{2 \text { therm }}}{\tau_{\mathrm{T}}}\right]
$$

ここで実効自然放出光結合係数 $\beta_{\mathrm{eff}}$ は

$$
\beta_{\text {eff }}=\left(\tau_{\mathrm{T}} / \tau_{\mathrm{R}}\right) \beta
$$

で与えられる。ただし

$$
\begin{aligned}
& \frac{1}{\tau_{\mathrm{T}}}=\frac{1}{\tau_{\mathrm{R}}}+\frac{1}{\tau_{\mathrm{NR}}} \approx \frac{1}{\tau_{\mathrm{NR}}}, \frac{1}{\tau_{\mathrm{NR}}}=\frac{1}{\tau_{32}}+\frac{1}{\tau_{31}} \\
& \tau_{\mathrm{T}} \approx \tau_{\mathrm{NR}} \approx 1 \mathrm{ps}, \tau_{\mathrm{R}} \approx 10 \mathrm{~ns}
\end{aligned}
$$

である。したがって $\beta_{\text {eff }}$ は上位準位 $(\mathrm{E} 3)$ からの高速の非 発光寿命 (〜ピコ秒)のため非常に小さな值となる。Mは カスケード結合の段数, $n_{\mathrm{sp}}$ は反転分布パラメータ, $\eta$ は ポンプ効率, $\gamma$ は共振器中の光子数の減衰率, $N_{2 \text { therm }}$ は下 位準位 $(\mathrm{E} 2)$ における電子の熱分布をそれぞれ表す。自 然放出光結合係数 $\beta$ は中赤外の場合 $10^{-3} \sim 10^{-5}$ であるので $\beta_{\mathrm{eff}}$ は $10^{-7} \sim 10^{-8}$ と非常に小さな值となる.したがってし きい值電流は本質的に高いと言えるが, カスケード結合 の段数 $M$ を稼ぐことによって緩和される構造となってい る. Fig. 2 に $\beta_{\text {eff }}=10^{-7}, \quad \gamma=5 \times 10^{11} / \mathrm{s}, \quad n_{\mathrm{sp}}=1.25, \quad \eta=1$ と して規格化した注入電流 $\left(I_{0} / I_{\mathrm{th}}\right)$ に対する非発光遷移, 誘 導放出, 自然放出の各レートを計算した結果を示す。誘 導放出レートのしきい值での増大が $2 \times 10^{8}$ 倍と巨大で, 一旦レーザー発振が起こってしまえば高い効率を確保で

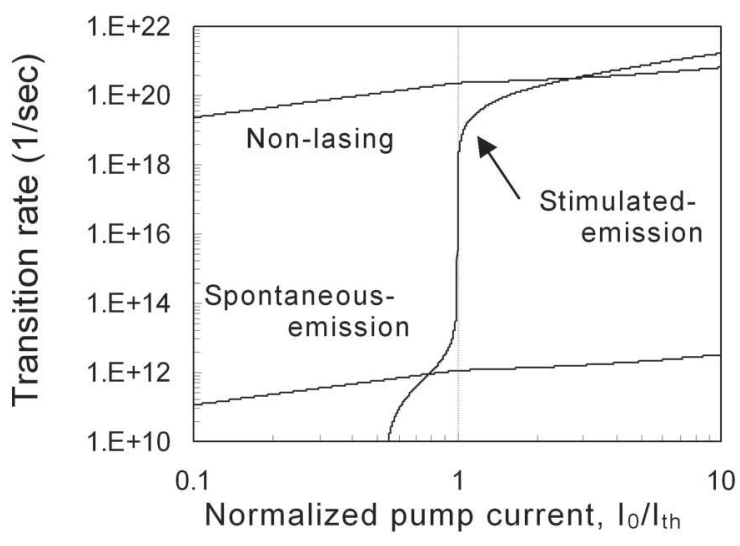

Fig. 2 Calculated transition rate of non-lasing relaxation, stimulated emission, and coupled spontaneous emission as a function of the normalized pump current $I_{0} / I_{\mathrm{th}}$.

きることがわかる，また，高い誘導放出レートはしきい 值直上での爆発的とも言える急激な光子数の増加によっ てもたらされ，結果として誘導放出レートはレーザー 発振モードに結合した自然放出レートに比べて7〜8桁程 度高くなる。ここで重要なことは，しきい值直上 $\left(I_{0} / I_{\text {th }}<1.5\right)$ では空間的に均一な非発光緩和レートが依然 として誘導放出レートより高いため, 上位準位の空間的 ホールバーニングが発生することなく安定な動作が維持 されうることである゙4.

\section{3. 高出力化}

QCLの活性領域はFig. 1に示されるような発光層と電 子注入層のペアが多段にカスケード結合した構造となっ ている．前段の電子注入層より E3に注入された電子は E2へと発光遷移し, さらにLOフォノン散乱を介して高 速にE1へ緩和する。高速緩和した電子は続く電子注入 層によって次段の発光層へと再び注入される，このよう な電子のリサイクリング効果によりカスケード結合の段 数を増やすことで高出力化が可能となる. 一般に光出力 およびスロープ効率はカスケード結合の段数Mに比例し て増大するため, 高出力化には単純に段数 $M$ を増加すれ ばよいことになる，ところが，段数 $M$ が増加するとそれ に伴って駆動電圧 $(1$ 段当りの電圧降下 $\times$ 段数) も増加し てしまう。駆動電圧の増加は素子の発熱をまねき, 光出 力が熱飽和する。したがって高出力化には段数 $M$ の最適 化や端面コーティングおよび長共振器構造によるミラー 損失の低減に加えて，熱伝導率に優れた材料選択といっ た放熱対策も重要となる.

これまでQCLの高出力化は主にセキュリテイ応用を目 的として波長4.5〜 $5 \mu \mathrm{m}$ で集中的に進められており, Razeghiたちのグループを中心に精力的に研究開発が行 われている。2005年に波長 $4.8 \mu \mathrm{m} て 200 \mathrm{~K}$ の低温ながら 平均光出力 $1 \mathrm{~W}$ 以上が達成年された。その後 2007 年には 室温で675 mWが報告7)された。これでは活性層段数30 段, 共振器長 $3 \mathrm{~mm}$, 後端面を高反射(High-Reflection: HR) コート，放熱対策として熱伝導率に優れたダイヤモ 
ンドを用いたヒートシンクにエピダウンでマウントして いる. これ以降, 長共振器化, ダイヤモンドヒートシン クの使用が主流となり2008年には半絶縁性FeドープInP による埋め込みへテロ (buried hetero: BH) 構造を用いて

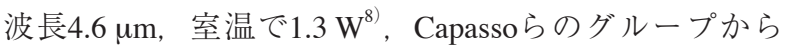
は2009年に共振器長 $5 \mathrm{~mm}$ で3 Wが報告9) された。現在で は後端面HRコート, 出射端面側を無反射 (AntiReflection: AR) コートで5.1 W( 波長 $4.9 \mu \mathrm{m}$, 共振器長 $5 \mathrm{~mm}$, BH構造, ダイヤモンドヒートシンク，エピダウ

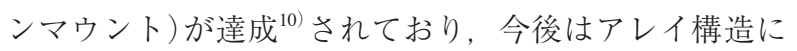
より数十ワットクラスのさらなる高出力化が進むものと 考えられる.

一方, $4 \mu \mathrm{m}$ 帯以外の波長ではあまり開発が進んでい ない状況である。特にサブバンド間のエネルギー差が $100 \mathrm{meV}$ を切るような長波長領域では上位準位寿命は極 端に短くなり, レーザー発振に必要な反転分布の形成が 非常に難しくなる。これまでのところ波長 $15 \mu \mathrm{m}$ では室 温パルス駆動が達成されており, ピーク光出力 $216 \mathrm{~mW}^{11}$ が得られているが, 波長が長くなるほど室温 でのレーザー発振は困難なものとなる。 さらに長波長領 域となる波長 $100 \mu \mathrm{m}$ 前後のいわゆる $\mathrm{THz}$ 帯と呼ばれる領

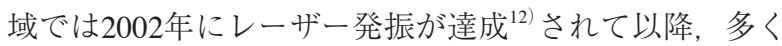
のグループで勢力的に研究開発が進められているが, 未 だに最高動作温度はパルス駆動で200 K以下 ${ }^{13)}$ であ。

THz帯におけるQCLのCW駆動は, Huらのグループに よって発振波長 $3 \mathrm{THz}$, 最高動作温度 $117 \mathrm{~K}$, 動作温度

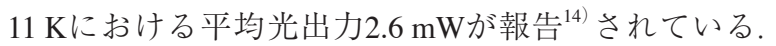
このように長波長領域ではレーザー発振そのものが困難 であるため, 高出力化にまでは至っていない状況であ り，その応用研究も限定的なものとなっている。

現在, 我々は医療応用を目的として, 様々な有機分子 の吸収ラインが存在する波長5.7 $6.1 \mu \mathrm{m}\left(\sim 1700 \mathrm{~cm}^{-1}\right.$ 付 近)で高出力QCLの研究開発を行なっている. 活性領域 はフォノン共鳴 - ミニバンド緩和 (Single-Phonon resonance Continuum depopulation: SPC) 構造 ${ }^{15)}$ となってい る. $\mathrm{SPC}$ 構造では従来構造で問題となっていた下位準位 の電子の流れを改善し, 効率的な反転分布形成のために LOフォノン散乱を介してミニバンドへ電子を落とし, ミニバンド内の高速緩和を利用する構造となっている.

Fig. 3にSPC緩和構造を用いた活性領域のバンド図を示 す. 非常に短い下位準位寿命 $(\sim 0.18 \mathrm{ps})$ を実現し, 且つ 下位準位からの緩和構造をミニバンドとすることで設計 および結晶成長が容易となり，許容範囲が広く安定した 動作が得られるという特徵を有している.

Fig. 4 に $20^{\circ} \mathrm{C} て ゙$ 駆動した場合の電流一光出力特性, お よびFig. 5に発振スペクトルを示す。n型InP基板上に MOCVD法により InGaAs/InAlAs超格子で構成されるSPC 構造QCLを成長した。素子はカスケード段数50段 $(M=50)$, 共振器長 $4 \mathrm{~mm}$, 端面はAR/HRコート, BH構 造で通常のCuヒートシンクにエピダウンでマウントし ている. duty-cycle:50\%(パルス幅500 ns, 繰返し1 MHz) のパルス駆動で, 中心波長6 $\mu \mathrm{m}$, 発振しきい值電流 $1.2 \mathrm{~A}$, 平均光出力 $1.1 \mathrm{~W}$ 達成した。尚, 発振スペクト

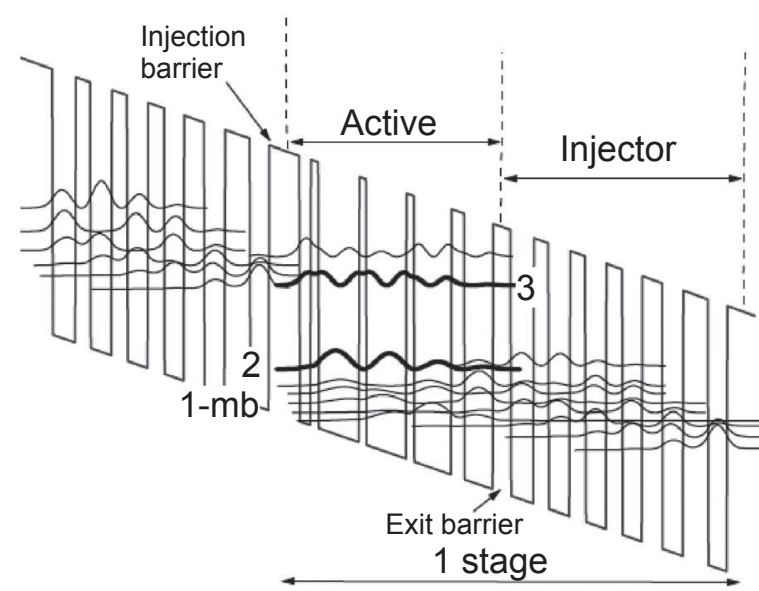

Fig. 3 Schematic conduction band diagram and moduli squared of the relevant wave functions in the designed active region of a SPC-QCL.

ル中に存在する鋭い吸収線は大気中の水蒸気 $\left(\mathrm{H}_{2} \mathrm{O}\right)$ によ るものである.

一般にQCLにおいては高出力動作においてもレーザー 発振に伴う素子内部の結晶あるいは端面における劣化は 存在せず，動作寿命は化合物半導体の電子デバイスと同 程度であると推測されている。これはQCLがユニポー ラーデバイスであり，動作中に放出される光子エネル

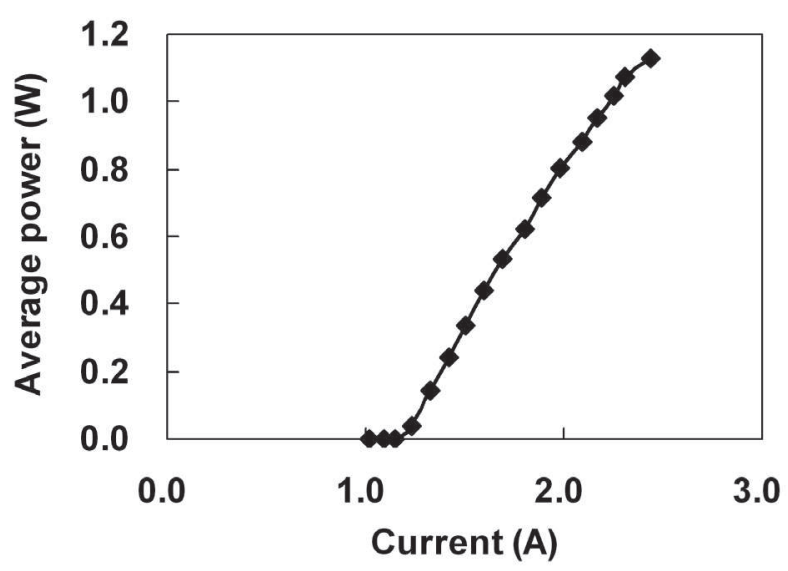

Fig. 4 Current-light output characteristic of a $6 \mu \mathrm{m}$ range QCL in pulsed operation at $20^{\circ} \mathrm{C}$.

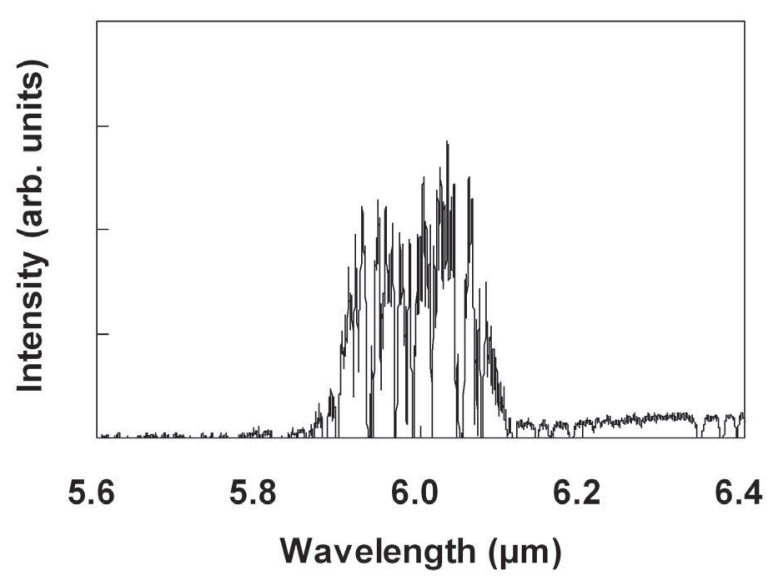

Fig. 5 Lasing spectrum of a $6 \mu \mathrm{m}$ range $\mathrm{QCL}$ at $20^{\circ} \mathrm{C}$. 
ギーが使用される半導体材料のバンドギャップに比べて 十分小さいことによるものと考えられる.

\section{4. 高出力QCLの医療応用}

一般にレーザー治療とは, レーザー光の照射により誘 起される光化学的, 熱的, 機械的な相互作用を介して治 療効果を得るものである。レーザー照射の条件を最適化 することによって，所望の相互作用を病変部位に選択的 に誘起し, 最小侵襲処置が可能となる。生体組織を構成 する生体分子は複雑な多原子分子から成っており，ある 特定の官能基の振動モードが存在する。例えばエステル 基の $\mathrm{C}=\mathrm{O}$ 伸縮振動モードは5.75 $\mu \mathrm{m}$, ヒドロキシル基の $\mathrm{OH}$ 変角振動モードは6.1 $\mu \mathrm{m}$ に存在する ${ }^{16)}$. レーザー光 の単色性による優れた波長選択性を利用して, ある特定 の振動モードを励起し選択的反応を誘起できる．従来は レーザー光照射による熱的効果のみを利用していたが, それぞれの振動モードに適した波長のQCLを照射するこ とにより，選択的なレーザー生体相互作用を起すことが 可能である. またQCLでは単なる光出力だけでなくパル ス幅, 繰返し周波数, duty-cycleなどの照射条件を広い 範囲で設定することができ, 熱的効果(凝固, 炭化を伴 う蒸散切開など)や機械的効果 (非熱的な蒸散切開など) を治療目的によって切り替え, 治療行為の低侵襲化を図 ることが可能になると期待される. 高出力QCLの生体組 織の凝固切開 (レーザーメス)への応用例として, Fig. 6 に生体軟組織(トリ胸部組織)へ高出力QCLを照射したと きの切削痕の断面像を示す。 QCLは中心波長5.75 $\mu \mathrm{m}$, $500 \mathrm{~ns} / 1 \mathrm{MHz}$ のパルス駆動である。平均パワー密度は $3400 \mathrm{~W} / \mathrm{cm}^{2}$ ，照射時間は $0.5 \mathrm{~s}$ で行なった。

現在, 注目されているレーザー治療のひとつとしてカ テーテルを用いた治療があげられる。 カテーテルとは医 療用の中空の管で, 消化管や尿管などの管腔部または血 管に挿入し, 検査や治療を行なうものである. カテーテ ル内にレーザー光を導光するファイバー(中赤外波長域 の場合は中空ファイバー)を入れ，患部に直接レーザー 光を照射する. カテーテルの太さは通常 $1 \mathrm{~mm}$ 以下であ るので術後の傷はほとんど残らない. また, レーザー光 照射中に痛みや熱さを感じることも少なく, 患者の肉体

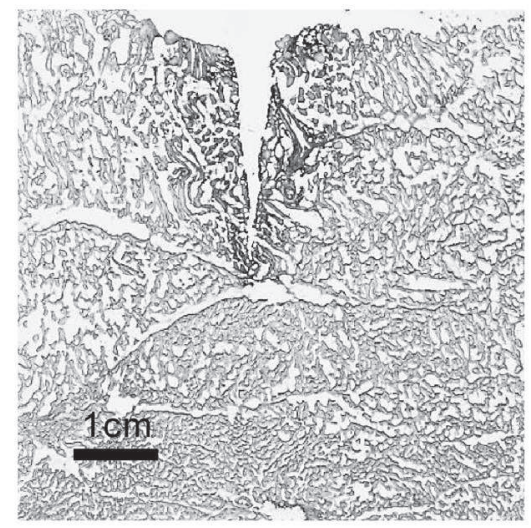

Fig. 6 Cross-sectional view of irradiated chicken breast tissue.
的および精神的負担を最小限に留めた治療法として理想 的である。具体的には動脈硬化部位の除去 ${ }^{17)}$, 尿管結石 や胆石の破砕などが考えられる ${ }^{18)}$.

粥状動脈硬化部位ではコレステロールが脂肪酸とエス テル結合した物質であるコレステロールエステルが主成 分のプラークが血管壁に蓄積している. エステル基の $\mathrm{C}=\mathrm{O}$ 伸縮振動モードに対応した波長5.75 $\mu \mathrm{m}$ のレーザー 光を照射することによってエステル結合に特異的に反応 を誘起し, 粥状動脈硬化部位を除去することが可能であ る。そこで動脈硬化部位の模擬サンプルとしてのコレス テロールオレイト薄膜, 正常動脈組織の模擬サンプルと してのブタ胸部大動脈血管に5.75 $\mu \mathrm{m}$ 高出力QCLを照射 し，動脈硬化治療への有用性を検討した ${ }^{19)}$ 。実験に使用 したコレステロールオレイト薄膜の厚さは約 $10 \mu \mathrm{m}$, ブ 夕胸部大動脈は生理食塩水処理した約 $5 \mathrm{~mm} \times 5 \mathrm{~mm}$ の切 片である。QCLは中心波長 $5.75 \mu \mathrm{m}, 500 \mathrm{~ns} / 1 \mathrm{MHz}$ のパ ルス駆動である。平均パワー密度は20～ $300 \mathrm{~W} / \mathrm{cm}^{2}$, 照 射時間は1〜30 sで行なった. Fig. 7に平均パワー密度50, $100 \mathrm{~W} / \mathrm{cm}^{2}$ ，照射時間 1 ， $5 \mathrm{~s}$ で照射したときのコレステ ロールオレイト薄膜の表面形状を示す。またFig. 8には ブタ胸部大動脈血管片に対して平均パワー密度100, $250 \mathrm{~W} / \mathrm{cm}^{2}$ ，照射時間 $1,10 \mathrm{~s}$ としたときの表面形状を示 す.

平均パワー密度 $30 \mathrm{~W} / \mathrm{cm}^{2}$ 以下では，いずれの照射時間

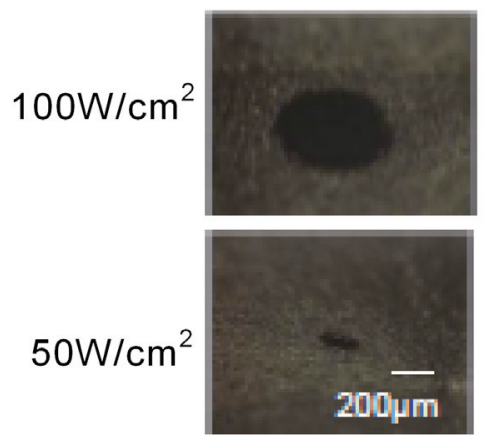

1
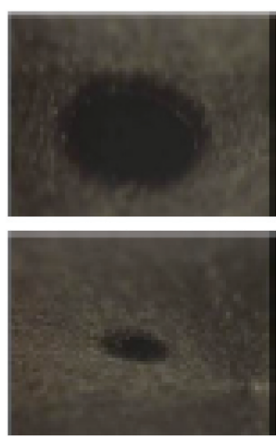

10

\section{Irradiation time (s)}

Fig. 7 Irradiation effect to cholesteryl orate thin-film.

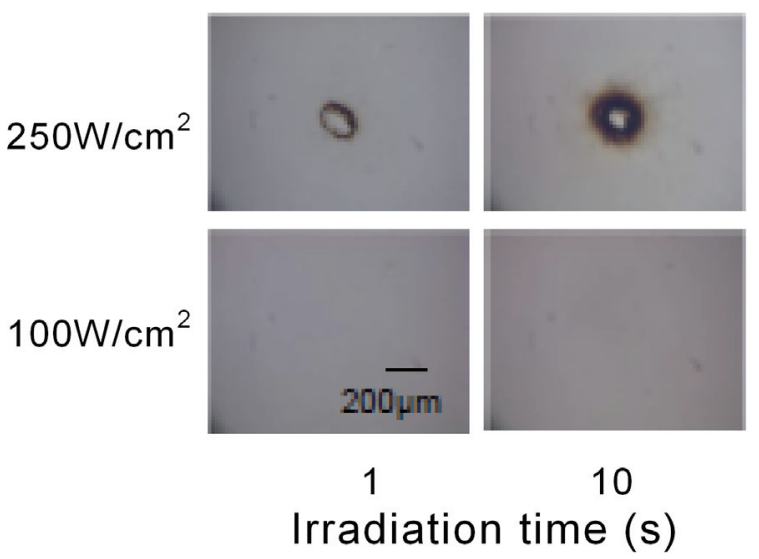

Fig. 8 Surface view of irradiated porcine thoracic aorta. 
でもコレステロールオレイト薄膜は変化がなく，50～ $100 \mathrm{~W} / \mathrm{cm}^{2}$ では照射時間 $1 \mathrm{~s}$ 以上で融解が確認された。一 方, ブタ胸部大動脈では平均パワー密度 $150 \mathrm{~W} / \mathrm{cm}^{2}$ では 変化なく, $200 \mathrm{~W} / \mathrm{cm}^{2}$, 照射時間 $1 \mathrm{~s}$ で熱変性, $5 \mathrm{~s}$ 以上で 炭化, $250 \mathrm{~W} / \mathrm{cm}^{2}$ 以上では照射時間 $1 \mathrm{~s} て ゙$ 炭化が確認され た. 以上の結果より正常動脈組織には損傷を与えずにコ レステロールオレイトを融解できることが認められ， QCLを用いた動脈硬化病变部位の選択的除去の可能性が 示された。今後は最適なレーザー照射パラメータの検討 が重要となる。実際の治療においては血管内で行なうた め血液やフラッシュ用生理食塩水中の水分による巨大な 吸収が存在する。そのため血管内環境と同様な湿潤状態 で選択的治療が可能な照射パラメータがどのような範囲 で存在するかについて検討を行なう必要がある。次のス テップとしてはウサギの動脈硬化病変を用いて照射パラ メータについて詳細な検討を行なう予定である。

\section{5. まとめ}

波長6 $\mu \mathrm{m}$ 帯のQCLにおいて, 活性領域の最適化およ び放熱対策により単素子で平均光出力 $1 \mathrm{~W}$ 以上の高出力 化を実現した。模擬サンプルへの照射実験により，選択 的な動脈硬化治療の可能性が示され, 安全性の高い(正 常組織には非侵襲) 治療方法として有望である。中赤外 領域の半導体レーザーである高出力QCLは固体レーザー を中心とした従来の医療用レーザーに比べて小型, 長寿 命, メンテナンスフリー, 低コストといった優位性があ り，今後は実機への導入が期待される。 また，アレイ構 造により数十ワットクラスが実現されれば波長 $5 \mu \mathrm{m}$ 以 上に強い吸収をもつ樹脂材料(フッ素系樹脂，スチレン 系透明樹脂など)への微細加工，マーキング， 溶着と いった直接加工, 中赤外ライダー (Light Detection And Ranging: LIDAR)，危険物質の遠隔イメージングなどへ の応用展開も可能である。
素子作製および評価に協力頂いた浜松ホトニクス(株) 中央研究所材料研究室, レーザーデバイス開発グルー プ, レーザー事業化部の諸氏に深く感謝致します。

\section{参考文献}

1) R. Kazarinov and R. Suris: Sov. Phys. Semicond. 5 (1971) 207.

2) J. Faist, F. Capasso, D. L. Sivco, C. Sirtori, A. L. Hutchinson, and A. Y. Cho: Science 264 (1994) 553.

3) M. Beck, D. Hofstetter, T. Aellen, J. Faist, U. Oesterle, M. Ilegems, E. Gini, and H. Melchior: Science 295 (2002) 301.

4) M. Yamanishi, T.Edamura, K.Fujita, N.Akikusa, and H.Kan: IEEE J. Q. Electron. 44 (2008) 12.

5) S. Bartalini, S. Borri, I. Galli, G. Giusfredi, D. Mazzotti, T. Edamura, N. Akikusa, M. Yamanishi, and P. De Natale: Opt. Express 19 (2011) 17996.

6) W. W. Bewley, J. R. Lindle, C. S. Kim, I. Vurgaftman, J. R. Mayer, A. J. Evans, J. S. Yu, S. Slivken, and M. Razeghi: IEEE J. Q. Electron. 41 (2005) 833.

7) A. Evans, S. R. Darvish, S. Slivken, J. Nguyen, Y. Bai, and M. Razeghi: Appl. Phys. Lett. 91 (2007) 071101.

8) Y. Bai, S. R. Darvish, S. Slivken, W. Zhang, A. Evans, J. Nguyen, and M. Razeghi: Appl. Phys. Lett. 92 (2008) 101105.

9) A. Lyakh, R. Maulini, A. Tsekoun, R. Go, C. Pflugl, L. Diehl, Q. J. Wang, F. Capasso, C. Kumar, and N. Patel: Appl. Phys. Lett. 95 (2009) 141113.

10) Y. Bai, N. Bandyopadhyay, S. Tsao, S. Slivken, and M. Razeghi: Appl. Phys. Lett. 98 (2011) 181102.

11) K. Fujita, M. Yamanishi, T. Edamura, A. Sugiyama, and S. Furuta: Appl. Phys. Lett. 97 (2010) 201109.

12) R. Kohler, A. Tredicucci, F. Beltram, H. E. Beere, E. H. Linfield, A G. Davies, D. A. Ritchie, R. C. Iotti, and F. Rossi: Nature 417 (2002) 156

13) S. Fathololoumi, E. Dupont, C. W. I. Chan, Z. R. Wasilewski, S. R. Laframboise, D. Ban, A. Matyas, C. Jirauschek, Q. Hu, and H. C. Liu: Optics Express 20 (2012) 3866.

14) B. S. Williams, S. Kumar, Q. Hu, and J. L. Reno: Optics Express 13 (2005) 3331.

15) K. Fujita, S. Furuta, A. Sugiyama, T. Ochiai, T. Edamura, N. Akikusa, M. Yamanishi, and H. Kan: Appl. Phys. Lett. 91 (2007) 141121.

16）石井克典，粟津邦男：医学のあゆみ 240 (2012) 511.

17）石井克典, 月元 秀樹, 間 久直, 粟津 邦男：日本レーザー 医学会誌 30 (2009) 126.

18) H. Hazama, S. Yamada, K. Ishii, and K. Awazu: Proc. SPIE 6991 (2008) $6991 \mathrm{H}$.

19) K. Hashimura, K. Ishii, N. Akikusa, T. Edamura, H. Yoshida, and K. Awazu: Proc. Conference on Laser Surgery and Medicine 2012 (2012) p.30. 